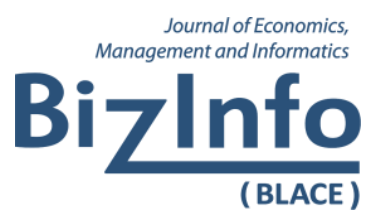

Year 2019, Volume 10, Number 2, pp. 139-153

Прегледни рад/ Review paper

УДК/UDC: 338.48-44(497.11-21 Ниш)

doi:10.5937/bizinfo1902139P

\title{
TOURIST RESOURCES OF THE CITY OF NIŠ IN THE FUNCTION OF ITS DEVELOPMENT AS AN URBAN TOURIST DESTINATION
}

\section{TURISTIČKI RESURSI GRAD NIŠA U FUNKCIJI NJEGOVOG RAZVOJA KAO GRADSKE TURISTIČKE DESTINACIJE}

\author{
Milena Podovac ${ }^{1}$ \\ University of Kragujevac, Faculty of Hotel Management and Tourism in \\ Vrnjačka Banja
}

Abstract: In this paper, the tourist resources of the city of Niš were analyzed. The primary objective of the analysis is to examine the possibilities of developing Niš as a urban tourist destination. On the tourist map of the Republic of Serbia, the main admiNištrative centers Belgrade and Novi Sad represent built urban destinations, visited by a large number of foreign tourists. On the other hand, Niš as a city with rich culture and history as well as high quality tourist resources, is still not sufficiently recognized as a urban destination. Accordingly, the analysis of the tourist resources of the city of Niš represents the basis for implementing guidelines for its future development as a urban destination.

Key words: Niš, city, urban tourist destination, urban tourism.

Sažetak: U ovom radu, analizirani su turistički resursi grada Niša. Primarni cilj analize je ispitivanje mogućnosti razvoja Niša kao gradske turističke destinacije. Na turističkoj mapi Republike Srbije, glavni admiNištrativni centri Beograd i Novi Sad predstavljaju izgrađene gradske destinacije, koje posećuje veliki broj stranih turista. Sa druge strane, Niš kao grad sa bogatom kulturom $i$ istorijom kao i kvalitetnim turističkim resursima, još uvek nije u dovoljnoj meri prepoznat kao gradska destinacija. Prema tome, analiza

\footnotetext{
${ }^{1}$ milena.podovac@kg.ac.rs
} 
turističkih resursa grada Niša predstavlja osnovu za izvođenje smernica za njegov budući razvoj kao gradske destinacije.

Ključne reči: Niš, grad, gradska turistička destinacija, gradski turizam.

\section{INTRODUCTION}

The development of tourism in the cities of the Republic of Serbia has enabled the proper valorisation and implementation of tourism resources into a unique tourist offer, which is intended for city tourists. The main drivers of urban tourism development in Serbia are Belgrade and Novi Sad. However, smaller cities also have a good foothold in tourism resources for urban tourism development (Podovac, 2016, p. 10). The subject of analysis in this paper, are the tourism resources of the city of Niš and examining the possibility of using these resources to make this city an urban tourist destination.

As one of the oldest cities in the Balkans, Niš has, thanks to its history, geostrategic position, natural and anthropogenic values, become one of the most important tourist destinations in the Republic of Serbia. It is located in the Nišava basin at the mouth of the Nišava River in the South Morava at $43^{\circ} 19^{\prime}$ north latitude and $21^{\circ} 54^{\prime}$ east longitude. In addition to being one of the most economically developed cities in the region of Southern and Eastern Serbia, Niš is also the administrative centre of the Nišava District and the regional centre of Southeastern Serbia (Official Website of the City of Niš, http://www.ni.rs). Its geographical position can be said to be extremely favourable because it is located at the crossroads of the Balkan and European roads. Through Niš, there are highways and railways connecting the north and south of the country. In addition, Niš is linked to the wider European continent by European Corridors X and VII (City of Niš, 2007, p. 5). It is a university centre with 13 faculties and one of the oldest European cities, as testified by numerous prehistoric finds on the territory of the city (Avramović, Perić, Komadina, 2016, p. 53).

According to the 2011 census (http://popis2011.stat.rs/) there are 260,237 inhabitants on the territory of the city of Niš, making it the third largest city in the Republic of Serbia. Being geographically well positioned in relation to other cities in Serbia and the closer European environment, Niš has significant potential for economic development in order to create economically favourable living conditions for the population. According to the 2017 data (City of Niš, 2017, p. 15), a total of 3,482 companies and 8,326 entrepreneurs are operating on the territory of the City of Niš. The structure of industrial production is dominated by the manufacturing industry with more than $99.5 \%$, with the most important industries being the production of electrical equipment, machinery, chemicals and chemical products, food 
TOURIST RESOURCES OF THE CITY OF NIŠ IN THE FUNCTION OF ITS DEVELOPMENT AS AN URBAN TOURIST DESTINATION

products and more. (City of Niš, 2017, p. 7-8). According to the data of the Statistical Office of the Republic of Serbia for 2018 (The Republic Statistical Office, Employees of the Republic of Serbia, 2018), employment in the City of Niš amounted to 79,285 people, or $5.1 \%$ more than the previous year. The accommodation and food sector employs 3,332 , or $15.4 \%$ more than in the previous year, when it amounted to 2,887 people.

\section{THE CONCEPT OF URBAN TOURISM DESTINATION}

The theoretical approach to the analysis of the concept of a city destination and its basic characteristics necessitates the explanation of the term tourist destination. The term tourist destination, in the literature, is defined in different ways. The term destination originates from the Latin word destinatio, which denotes destination, orientation, purpose and ultimate goal (Popesku, 2016, p. 27). The term resort is also present in the literature, which is very often interpreted in the same way as a tourist destination, although Prideaux $(2009$, p. 10) points out that this phenomenon is the result of the use of these terms in the tourism industry by tourism policy makers. Taking into account the fact that a resort can be defined in a narrow sense as a hotel complex, which in one place offers all the services needed to meet the needs of tourists, to the definition including wider tourist destinations, in which cities can be classified, the concept of destination is much broader than that of resort (Zečević, 2007, p. 29).

Buhalis (2000, p. 97) defined tourist destinations as amalgams of tourist products, which offer an integrated experience to consumers and tourists. Creating an authentic experience for tourists can be an essential prerequisite for securing a competitive advantage in the tourism market. The tourist destination represents a more or less rounded geographical unit, which has attractive, communicative and receptive factors, that is, all those natural, social, anthropological, cultural-historical, traffic and prerequisites for accommodation and food, rest, entertainment and recreation (Bakić, 2002, p. 6). A tourist destination should be viewed as an entity of different geographic scope, which has the necessary elements to provide a unique experience for tourists. The complexity of the concept of tourist destination is also related to the very nature of the tourist destination, which is a large system, composed of a large number of entities involved in the process of providing services to tourists.

Cities became significant tourist destinations in the 1980s (Dunne, 2009, p. 10), when there was heavy unemployment in industrial cities, making tourism recognized as an activity that can contribute to solving this problem. The role of tourism resources in urban regeneration has been recognized by governments as an opportunity for prosperous economic development. Law 
(1993) identified four factors for involving cities in tourism development: declining production activities, the need to create new economic activities to reduce unemployment, the image of tourism as a growing segment of the tourism industry, and expectations that tourism development will be driven by urban regeneration and revitalization of city centres.

Cities represent one of the oldest tourist destinations, visited by tourists due to different motives (cultural, historical, etc.), but are also perceived by tourists as a business tourism destination (Popescu and Profiroiu, 2012, p. 221). Accordingly, cities can be classified as tourist destinations on the basis of several factors: an urban area of dense population, which attracts a large number of tourists; gateway to other tourist destinations; the emphasis is on the development of industry, economy and trade; centre of various services (educational, administrative, health, etc.) and a place where the tourist acquires different experiences (Anuar, Bookhari and Aziz, 2012, p. 478). The city represents a system of tourist resources, which are connected by a large number of interests in getting to know the destination, its history, art, lifestyle and other forms of urban identity (Peroš, 2013, p. 217).

The city as a tourist destination can also be viewed from the perspective of tourists' perception, which makes different cities visible to tourists in different ways. In addition to tourism resources, an important segment of the city's development as a tourist destination is its image, which is very important for creating a positive image in the minds of tourists. The literature presents a large number of classifications of urban tourist destinations, which are defined based on different criteria. One of the first classifications of urban destinations was set by Fainstein and Judd (1999), who viewed cities from the aspect of tourism development:

1) City resorts, built to develop tourism;

2) Tourist-historical cities, whose cultural heritage is the primary tourist attraction;

3) Transformed cities, in which the city and its way of functioning have evolved to development of tourism.

Although it covers only three types of urban destinations, this division is made depending on the degree of importance of tourism for the development of the city. In this respect, there is a noticeable difference between cities where tourism is developing as a leading activity and those where the city has adapted to the development of tourism. A very similar approach is represented by Page (1995), whose division of urban destinations is based on the purpose of the city, which is why he classified them as follows: capitals, metropolises, large historic cities, inland metropolitan areas, revitalized cities, industrial cities, coastal towns and winter sports centres, purpose-built integrated tourist resorts, tourist-entertainment complexes, specialized tourist 
TOURIST RESOURCES OF THE CITY OF NIŠ IN THE FUNCTION OF ITS DEVELOPMENT AS AN URBAN TOURIST DESTINATION

service centres and cultural and artistic cities. The classification, given by Page, indicates the ability of the city as a destination to satisfy a large number of tourist needs and motives of tourists of different socio-demographic characteristics. On the other hand, Hall (2002, p. 235-248), in his classification, pointed to the importance of major cities (capitals) as tourist destinations, namely: multifunctional capitals, global capitals, political capitals, former capitals, former imperial capitals, provincial capitals and capitals that function as the headquarters of large international organizations. The aforementioned classification makes it possible to group the same cities into a number of different categories, which makes it difficult to define a unique division of urban destinations. In relation to the mentioned authors, Law (1996) used the city's attractions as a criterion for the division of urban destinations. In his classification, the following city destinations are represented:

1) Capital cities, which possess a large number of anthropogenic resources;

2) Industrial cities, which have experienced prosperity due to the development of industry and commerce;

3) Cities with a high concentration of tourist facilities (natural landscapes, attractions, entertainment, etc.);

4) Highly attractive, multifunctional and touristy cities for holidays and entertainment.

Taking into account the above classifications, it is evident that the authors used different criteria for division. This allows one city to be classified into more than one category of city destinations. On the other hand, cities differ in their basic characteristics (territory, form of government, population, economic development, etc.) but also in terms of quality and quantity of tourism development resources. In the context of tourism development, the most important are the resources that a city possesses and can use to create a tourism offering, while on the other hand, the status of the city may not be crucial in the division of urban destinations. In this paper, the classification of urban destinations, defined by Law (1996) according to which the city of Niš, can be classified into a group of highly attractive cities, was used.

\section{ANALYSIS OF TOURIST POTENTIALS OF THE CITY OF NIŠ}

\subsection{NATURAL AND ANTHROPOGENIC RESOURCES}

The natural predispositions of the city of Niš, related to the favourable geographical position, climatic characteristics, flora and fauna, hydrographic potential, etc., have a favourable influence on the development of almost all forms of tourism. The city of Niš is located in the Niš valley at 194 meters above the sea level, with the highest point being the Sokol's stone $(1,523$ 
meters above the sea level). The climate is temperate-continental. The relief is very specific due to the existence of the Sićevo Gorge, which is $17 \mathrm{~km}$ long and has a depth of $400 \mathrm{~m}$. The terrain configuration is very specific due to the large number of gorges, canyons, caves, etc. (City of Niš, 2009, p. 24). The hydrographic potential consists of South Morava and Nišava (Official Gazette, 2011, p. 7). Of the total city territory, green areas occupy as much as 18\% (Secretariat for Environmental Protection of the City of Niš, 2017, p. 60). Significant nature monuments are valorised and included in the tourist offer, which include: the Gorge of Sićevo, Jelašnica Gorge, The Hill of Kamenica, the Cave of Cerjevo and other. The Nature Park of the Gorge of Sićevo represents the narrowing of the Nišava River valley. The tourist value of the gorge is the remains of some 30 monasteries and a church of great cultural and historical value. The tourist offer is complemented by the accommodation facilities of the Hotel Sićevo with sports and recreational facilities. The Sićevo Gorge is significant for the development of ecotourism, picnic and sports-recreational tourism. The Jelašnica Gorge Special Nature Reserve is located $15 \mathrm{~km}$ from Niš. It is abundant in natural attractions such as waterfalls, stone rocks and rare plant species. Special Nature Reserve Suva planina is a mountain massif of favourable climatic characteristics with the highest peak Trem (1,810 m) (City of Niš, 2011, p. 19-20). The Hill of Kamenica Forest Park is a site where excursion tourism is developed. It is located on the branches of the Svrljig Mountains at an altitude of about $800 \mathrm{~m}$. Since it is located in the immediate vicinity of the city, it is part of the tourist offer for tourists, who come mainly for active holidays. As a natural monument on the territory of the City of Niš the Cerjan Cave is classified, located at 515 of meters above sea level. Its attractiveness are the corridors and halls, which contain various morphological and hydrological forms, stalactites, stalagmites, etc. Due to its natural value, it has been protected since 1998 as a natural asset of the first category (Official Website of the Tourist Organization of City of Niš, http://www.visitnis.com/).

The rich history of the origin and development of the city of Niš is evidenced by numerous sites of cultural and historical heritage. On the territory of the city, 66 archaeological sites and 265 registered cultural assets are recorded. However, the sites are not equally included in the existing tourist offer. The most important sites of cultural and historical heritage are: archaeological complex Mediana, which spans at 60 ha and is the residence of Emperor Constantine with preserved mosaics and marble statues; the ambient whole of Niš Fortress; a unique monument made from the skulls of fallen Serbian soldiers in the battle at Čegar the Skull Tower, a 19th century monument on Čegar erected in honour of Stevan Sindjelić, a large number of sacral objects, archaeological excavations, etc. (City of Niš, 2009, p. 48). The existing structure of cultural resources has enabled the development of cultural tourism, which is part of the offer and urban tourism, given the abundance of 
TOURIST RESOURCES OF THE CITY OF NIŠ IN THE FUNCTION OF ITS DEVELOPMENT AS AN URBAN TOURIST DESTINATION

sites of cultural and historical heritage in the urban segment of Niš. The offer of the city of Niš also includes manifestation content, which promotes contemporary culture and art. Music and film events are held in Niš, such as the Nisville International Jazz Festival, the Nisomnia Music Festival, and the film Festival Film Encounters (Jovanović-Tončev, Podovac, 2014, p. 59).

\subsection{TRAFFIC INFRASTRUCTURE}

The transport infrastructure is well developed and involves all kinds of traffic. Important international road and railroads pass through Niš, connecting the Balkans with Central and Western Europe, then the Vlach Lowlands and Pomoravlje with the Adriatic, Aegean and Black Sea. Development of the road network is crucial for traffic flow in the territory of the city of Niš. The road network is $391 \mathrm{~km}$ long and is dominated by local roads $(68 \%)$. The fact that it is located on the European corridor X places Niš in the order of transit tourism destinations with the appropriate structure of accommodation facilities, restaurants, markets, gas stations, etc. (City of Niš, 2007, p. 39). Niš also has a train station, located in the wider city centre with 6 tracks, with daily traffic flowing to nearby European cities, but also at local and national level (City of Niš, 2011, p. 29). In Niš, air traffic takes place at the Constantine the Great Airport, which opened for air traffic in 1986 (Official website of the Constantine the Great Airport, https://nisairport.com/istorijat/). It is located at a distance of $4 \mathrm{~km}$ from the city of Niš, near two main thoroughfares on Corridor $\mathrm{X}$, which lead to Bulgaria and Turkey and to the south of Europe (The City of Niš, 2017, p. 9). At the Constantine the Great, three airlines (Wizz Air, Ryanair and SWISS) operate air traffic and from June 2019 also Air Serbia (Official website of the Constantine the Great Airport). The number of passengers in 2018 amounted to 351,581 passengers, which is $6 \%$ more than in 2017 with 331,582 passengers. The number of flights realized in 2018 amounted to 1,417 flights, with a decrease of $4 \%$ compared to 2017 , when 1,477 flights were realized (Official website of the Constantine the Great Airport, https://nisairport.com/statistika/).

\subsection{ACCOMMODATION CAPACITY STRUCTURE}

Niš's accommodation offer is based on hotel accommodation, which includes 25 facilities with a capacity of 991 beds (Table 1). Four-star hotels (5 facilities with a capacity of 316 beds) and three stars (4 facilities with a capacity of 274 beds) have a significant share in the total hotel offer (Ministry of Trade, Tourism and Telecommunications - Tourism Sector, http://mtt.gov.rs/sektori/sektor-za-turizam/). However, the main disadvantage of the accommodation offer is the lack of a 5 star hotel, which provides top quality service to guests. Opening of Constantine the Great Airport and 
continuous improvement of the tourist offer of the city of Niš can influence the attraction of large hotel chains to expand their business by opening a facility in the territory of Niš. The highest percentages were recorded by fourstar hotels (32\%) and three-star hotels (27\%). Regarding garni hotels, the highest percentage share in the total hotel supply is provided by three-star garni hotels $(21 \%)$. ${ }^{1}$ The total number of private accommodation facilities is 57 with 154 rooms. Private accommodation is dominated by 3 star apartments ( 25 facilities with 159 beds) and 2 star apartments ( 21 facility with 35 beds). 4-star apartments ( 3 facilities with 12 beds) and 1-star apartments (1 facility with 156 beds) are much less represented (City of Niš, 2017, p. 17). Private accommodation is often used in the territory of the city of Niš for short stays in the city. For the development of tourism in Niš, an important factor in the overall offer is the accommodation capacities and quality of their services, which they provide to tourists during their stay in the destination.

Table 1. The offer of accommodation capacities in hotels of Niš

\begin{tabular}{|l|c|c|c|c|}
\hline \multicolumn{1}{|c|}{ Category } & $\begin{array}{c}\text { Number of } \\
\text { objects }\end{array}$ & $\begin{array}{c}\text { Number } \\
\text { of rooms }\end{array}$ & $\begin{array}{c}\text { Number of } \\
\text { apartments }\end{array}$ & $\begin{array}{c}\text { Number of } \\
\text { beds }\end{array}$ \\
\hline Garni hotel $*$ & 1 & 11 & 1 & 21 \\
\hline Garni hotel $* *$ & 2 & 16 & 4 & 31 \\
\hline Garni hotel $* * *$ & 8 & 120 & 7 & 215 \\
\hline Garni hotel **** & 2 & 21 & $/$ & 32 \\
\hline Hotel * & 1 & 17 & $/$ & 29 \\
\hline Hotel $* *$ & 2 & 48 & $/$ & 73 \\
\hline Hotel $* * *$ & 4 & 153 & 9 & 274 \\
\hline Hotel $* * * *$ & 5 & 180 & 12 & 316 \\
\hline Total & $\mathbf{2 5}$ & $\mathbf{5 6 6}$ & $\mathbf{3 3}$ & $\mathbf{9 9 1}$ \\
\hline
\end{tabular}

Source: Ministry of Trade, Tourism and Telecomunications - Sector for Tourism: http://mtt.gov.rs/sektori/sektor-za-turizam/korisne-informacije-turisticki-promet-srbijakategorizacija/, data for first quarter of 2019.)

\subsection{TOURISM CIRCULATION IN NIŠ}

Table 2 shows the data on tourist traffic in the city of Niš for the period from 2010 to 2018. The main feature of tourist traffic in the city of Niš is the very frequent fluctuations in the number of tourist arrivals and nights per year. However, despite the fact that Niš tourist traffic does not have a uniform growth rate, the share of foreign tourists in the total tourist traffic in the observed period is generally higher than the share of domestic tourists. Between 2010 and 2018, there was a 39.3\% increase in tourist arrivals. On the other hand, there was a decrease in the number of overnight stays in the observed period, thus a decrease of $46 \%$ was recorded. The largest number of

\footnotetext{
${ }^{1}$ The percentage share refers to the share of the number of hotel rooms of certain categories in the total number of hotel rooms in the territory of the city of Niš.
} 
TOURIST RESOURCES OF THE CITY OF NIŠ IN THE FUNCTION OF ITS DEVELOPMENT AS AN URBAN TOURIST DESTINATION

tourists stayed in Niš during 2018, at 122,839, with the percentage of foreign tourists in the total number of tourists 59\%. The growth in tourist arrivals in 2018 was about $15 \%$ compared to 2017 . The highest number of overnight stays of tourist in Niš was realized in 2010 and amounted to 309,658 nights with a percentage share of foreign tourists' nights in the total number of nights, $17.7 \%$. The worst result was achieved in 2013 , when only 63,050 tourists stayed in Niš. The lowest number of tourist overnight stays in the city of Niš was realized in 2013 and amounted to 122,509. The highest share of foreign tourists in the total number of arrivals was recorded in 2018 and amounted to $59 \%$, while the highest share of foreign tourists in the total number of overnight stays was recorded in the same year and amounted to about $49.5 \%$.

Table 2. Number of visitors in Niš in the period 2010-2018.

\begin{tabular}{|c|c|c|c|c|c|c|}
\hline \multirow[b]{2}{*}{ Year } & \multicolumn{3}{|c|}{ Arrivals } & \multicolumn{3}{|c|}{ Overnights } \\
\hline & $\begin{array}{c}\text { Domestic } \\
\text { tourists }\end{array}$ & $\begin{array}{l}\text { Foreign } \\
\text { tourists }\end{array}$ & Total & $\begin{array}{c}\text { Domestic } \\
\text { tourists }\end{array}$ & $\begin{array}{l}\text { Foreign } \\
\text { tourists }\end{array}$ & Total \\
\hline 2010. & 51.368 & 36.811 & 88.179 & 254.834 & 54.824 & 309.658 \\
\hline 2011. & 52.861 & 36.091 & 88.952 & 244.906 & 50.334 & 295.240 \\
\hline 2012. & 45.986 & 31.796 & 77.782 & 235.505 & 51.252 & 286.757 \\
\hline 2013. & 32.989 & 30.061 & 63.050 & 72.827 & 49.682 & 122.509 \\
\hline 2014. & 31.297 & 37.391 & 68.688 & 71.714 & 58.532 & 130.246 \\
\hline 2015. & 34.924 & 41.045 & 75.969 & 83.053 & 65.140 & 148.193 \\
\hline 2016. & 40.419 & 44.629 & 85.048 & 90.175 & 70.772 & 160.947 \\
\hline 2017. & 46.848 & 60.036 & 106.884 & 95.467 & 93.263 & 188.730 \\
\hline 2018. & 50.294 & 72.545 & 122.839 & 101.892 & 110.022 & 211.914 \\
\hline
\end{tabular}

Sources: Statistical Office of the Republic of Serbia, Municipalities and regions in the Republic of Serbia (2010-2018), Available at http://www.stat.gov.rs/oblasti/ugostiteljstvo-iturizam/; Tourist traffic - December 2018., Available at

http://publikacije.stat.gov.rs/G2019/Pdf/G20191016.pdf, (Accessed 16 April 2019)

\subsection{TOURIST PRODUCTS}

According to the Niš Tourism Development Program, Niš tourism products are divided into three categories (City of Niš, 2017, p. 19-22):

- The first category consists of tourism products, which are already well positioned in the market with a tendency for further development and commercialization - short city vacations, cruises, special interest tourism and active holidays.

- The second group includes tourism products, which have a certain position in the tourism market, but whose development requires a longer period - congress tourism and MICE tourism, events and health tourism. 
- The third category is tourism products, for which there are adequate potentials but which are poorly developed - rural tourism, ecotourism and mountains and lakes.

City tourism, or city vacations, are among the most important tourist products of the city of Niš. Although in terms of urban tourism development, Niš is far behind the main administrative centres of Serbia, this form of tourism is based on weekend visits by tourists from neighbouring European cities and shorter vacations during New Year holidays. An important factor in the development of urban tourism is the introduction of low-cost flights from 2015 (City of Niš, 2017, p. 20), thus enabling tourists to travel with different purchasing power. In addition, the promotion policy of the Tourist Organization of the City, which included marketing campaigns, fairs, websites, etc., contributed to the positioning of Niš as a completely new and under-explored destination for city holidays. Round trips, which involve visiting the sites of cultural and historical heritage and learning about tradition, are the basis for expansion thanks to the increase in the number of cities with which Niš is connected by airline services (City of Niš, 2017, p. 20-21).

Special interest tourism and active holidays are constantly increasing in terms of diversity and number of activities for tourists during their stay in Niš. The development of these tourism products involves the conception of activities for the stay of tourists in the countryside and playing certain sports as well as extreme sports. In the city of Niš, tourists can do horse riding, speleology, paragliding, diving, free climbing, mountain biking, etc. (Official Website of the Tourist Organization of City of Niš, http://www.visitnis.com/). This kind of activity allows tourists to stay in nature and to play sports in the preserved natural space. Special interest tourism in the city of Niš is developing owing to the existence of associations and organizations that promote and work on the popularization of sports and various hobbies (Čegar and Nonius Equestrian Clubs, Safari Club Recreational Organization, Grunf Paragliding Club, Niš Mountaineering and alpine-expedition Club and (Official Website of the Tourist Organization of City of Niš, http://www.visitnis.com/).

The health tourism of the city of Niš is based on the healing properties of the waters that originate in Niška Banja, which is the main carrier of the development of this form of tourism. Niška Banja is a natural health resort with radioactive water, which has two warm radioactive wells (Main Well and Dry Spa). The healing properties of water are used to treat a large number of diseases (nervous diseases, gynaecological diseases, respiratory diseases, etc.) (City of Niš, 2011, p. 18). The massif of the Svrljig Mountains and the Svrljig Gorge, which creates favourable climatic conditions, surrounds Niška Banja. In addition to the healing properties of water, the use of various 
TOURIST RESOURCES OF THE CITY OF NIŠ IN THE FUNCTION OF ITS DEVELOPMENT AS AN URBAN TOURIST DESTINATION

therapies includes expert medical staff that, in addition to water, uses gas radon and mud for therapeutic purposes. This tourist product is relatively modestly developed considering that besides Niška Banja; there is a spa \& wellness centre, Sense, located at the Radon Hotel (Official Website of the Tourist Organization of City of Niš, http://www.visitnis.com/). Niška Banja has the potential for tourism development. However, the tourist traffic of Niška Banja is not adequately proportional to its natural resources and material basis for tourism development (Gligorijević and Petrović, 2010, p. 316). The quality of the offer and the variety of medical and spa \& wellness services is not at the level of other spas in the Republic of Serbia, which is why this product is in a stagnant stage of its development. Continuous implementation of new types of services, which are primarily intended for the rest and recreation of tourists with the use of healing factors, can be a driving factor for the development of health tourism and the recognition of Niška Banja in the tourist market.

Manifestation tourism is one of the most promising tourism products of the city of Niš, which requires more efficient promotion of events in order to attract tourists. Festivals and cultural events in Niš include tourist events, fairs, cultural, sports, business and other events organized on various occasions and with appropriate facilities (Mandarić and Stamenković, 2017, p. 68). Unfortunately, the existing events are not directly related to the increase of the number of tourists during their period of holding. The only one that can be singled out in this sense is the Nisville Jazz Festival, which, unlike other events, attracts tourists to Niš during its events. Since this festival is organized within the Niš fortress, the ambience itself encourages tourists to attend this festival (Official Website of the Tourist Organization of City of Niš, http://www.visitnis.com/).

Congress tourism has been stagnant over the long term due to the closure of a number of hotels. Most congresses, which are organized, are medical in nature and are organized in the Radon stationary in Niška Banja. The organizers of smaller gatherings are the hotels Niški cvet, My Place, Tammy Residence and other. The main problem in the development of congress tourism in the city of Niš is the accommodation of participants of meetings in hotels of smaller capacity. This problem complicates communication and contact between people outside the congregation so that the improvement of the quality of congress tourism depends on the construction of a multifunctional congress centre (Šušić and Mojić, 2014, p. 536). In this way Niš would approach the leading destinations of congress tourism in Serbia, primarily Belgrade and Novi Sad. Improvement of the congress tourism offer would lead to an influx of more tourists and thus tourism revenues, but also Niš would be recognized as a tourist destination within the MICE industry at the level of the Republic of Serbia. The natural resources of the city of Niš 
and its surroundings create the conditions for the development of ecotourism, which is in its infancy. The Gorge of Sićevo, Jelašnica Gorge, Suva planina, the Cave of Cerjevo and The Hill of Kamenica are potentials for development of eco tourism (Secretariat for Environmental Protection of the City of Niš, 2017, p. 126). Rural tourism is underdeveloped in Niš. The lack of registered rural households is one of the reasons for the lack of a clearly defined rural tourism offer. On the other hand, rural areas are located in close proximity to the city with good transport infrastructure. The development of rural tourism can be focused on the organization of a large number of activities on agricultural land, active holidays, stay on the rivers, hunting and fishing, visiting cultural and historical sites (City of Niš, 2017, p. 22).

\section{CONCLUSIONS}

Niš is a tourist destination, which has great potential to position itself after Belgrade and Novi Sad as a city tourism destination on the territory of the Republic of Serbia and to become recognizable on the international tourist market. Geostrategic position, resource structure, quality of transport infrastructure and accessibility of Niš as A tourist destination are the main preconditions for more intensive development of urban tourism. The historical development of Niš, accompanied by significant events and personalities from the past, partly predetermined the present development of Nis. Its economic development is at a much higher level of development, including tourism, than other cities belonging to the Nišava district. The natural resources of the city of Niš favour the development of tourism and its specific forms; while on the other hand, a large number of registered sites of cultural heritage are valorised and included in the tourist offer. Natural attractions in the form of canyons, rivers, mountains, etc., have been used for the development of sustainable forms of tourism such as nature holidays, sports and recreational, excursion tourism, etc.

The key tourism products of the city of Niš include, above all, urban, business and manifestation tourism, as well as potentially attractive tourist products such as spa, rural, special interest tourism and more. Urban tourism, over a longer period, can greatly contribute to the better position of Niš as a tourist destination, given its resource structure and the number of tourists. On the other hand, the long-term competitive development of urban tourism depends on the intensive promotion of Niš on the international tourism market, as well as on the continuous improvement of the quality of the city tourism offer, especially in the field of organizing short tours of the city for foreign tourists with a professional guide service. Business tourism, i.e. the congress tourism sub-segment, is one of the significant tourist products of the city of Niš, having in mind the existing congress facilities. The improvement of the existing congress tourism offer requires the existence of multifunctional congress centres for the organization of international business 
TOURIST RESOURCES OF THE CITY OF NIŠ IN THE FUNCTION OF ITS DEVELOPMENT AS AN URBAN TOURIST DESTINATION

meetings. The organization of a large number of cultural events during the year is particularly important for the development of city tourism, which complements the offer for city tourists. In addition, a large concentration of foreign tourists is represented during the events, which makes the effects of tourism far greater throughout the economy of the city of Niš.

The urban part of the city, that is, its resources, is involved in the development of urban tourism, which is inseparable from cultural tourism, given that city tourists are interested in cultural heritage and events. In terms of transport infrastructure, the advantage of the city of Niš is the existence of the airport, which greatly facilitates the arrival of foreign tourists. The existence of regular and charter lines for a large number of broadcasting countries is an essential precondition for the development of city tourism in the city of Niš in the future. The city of Niš has a modest accommodation offer according to the number of facilities. The developers of the accommodation offer are hotels, with the highest number of three- and fourstar facilities. In addition to the hotels, a significant number of accommodation facilities are privately owned with a modest capacity in terms of number of beds. The development of the city of Niš as a city tourist destination is conditioned by the improvement of the quality and structure of the accommodation offer by opening five-star hotels, hostels for the younger population as well as introducing additional contents for tourists in the existing four-star hotels. The main characteristics of tourist traffic in the city of Niš are reflected in the continuous increase in the number of tourists, with a much higher number of foreign tourists, while the average tourist retention in the city, especially foreign ones, is lower than in relation to the other analyzed cities. Effective marketing activities, which would be based on the cooperation of the Tourist Organization and the holders of the tourist offer with the presentation of the tourist offer at international fairs, would contribute to a better image of the city of Niš on the foreign tourist market.

\section{REFERENCES}

1. Anuar, A. N. A., Bookhari, S. N. and Aziz, N. A., 2012. The effectiveness of Safe City Programme as safety basic in tourism industry: Case Study in Putrajaya. Procedia-Social and Behavioral Sciences, 42, pp.477-485.

2. Avramović, M., Perić, G., Komadina, M. 2016. Trends in business tourism with a special focus on the city of Niš as a conference destination. BizInfo (Blace) Journal of Economics, Management and Informatics, 7 (1), pp.47-59.

3. Bakić, O., 2002. Marketing menadžment turističke destinacije. Beograd: Ekonomski fakulet u Beogradu.

4. Buhalis, D., 2000. Marketing the Competitive Destination of the Future. Tourism Management, 21 (1), pp. 97-116. 
5. Dunne, G., 2009. Motivation and Decision Making in City BreakTravel: The case of Dublin. VDM Publishing; Saarbrucken, Germany.

6. Fainstein, S.S. and Judd, D.R., 1999. Cities as places to play. Preuzeto od: Judd, D.R. and Fainstein, S.S., 1999. The Tourist City. New Haven, CT: Yale University Press.

7. Gligorijević, Ž. i Petrović, J., 2010. The position of Niška Banja (Niš spa) in Serbian spa tourism. Facta Universitatis, Series: Economics and Organization, 7 (3), str. 309-317.

8. City of Niš., 2009. Strategy for the development of small and mediumsized enterprises and entrepreneurship in Niš 2009-2013. Niš.

9. City of Niš, 2007. Development Strategy of City of Niš. Niš.

10. City of Niš, 2009. Revision of the Development Strategy 2009-2020 City of Niš. Niš.

11. City of Niš, 2011. Tourism Development Strategy of the City of Niš 2011-2016. Niš.

12. City of Niš, 2017. Local Economic Development Program of the City of Niš for 2017. Niš.

13. City of Niš, 2017, Tourism Development Program of city of Niš with action plan for the period 2018-2020. Niš. [pdf] Available at: <http://www.ni.rs/wp-content/uploads/Program-razvoja-turizma-1820.pdf > [Accessed 15 June 2019].

14. Hall, C.M., 2002. Tourism in capital cities. Tourism: An International Interdisciplinary Journal, 50 (3), pp.235-248.

15. Jovanović-Tončev, M. i Podovac, M., 2014. Kulturna dobra kao deo turističke ponude banja Srbije. Ekonomija teorija i praksa 7 (3), str. 54-67.

16. Law, C. M., 1993. Urban tourism atrracting visitors to large cities. Mansell Publishing Limited.

17. Law, C.M., 1996. Tourism in Major Cities. International Thomson Business Press.

18. Mandarić, M., i Stamenković, I., 2017. Istraživanje značaja manifestacija za razvoj i brendiranje grada Niša kao turističke destinacije. HiT Menadžment-Menadžment u hotelijerstvu i turizmu, 5 (1), str. 64-74.

19. Ministry of Trade, Tourism and Telecommunications - Tourism Sector. [online] Available at: <http://mtt.gov.rs/sektori/sektor-zaturizam/korisne-informacije-turisticki-promet-srbija-kategorizacija/> [Accessed 16 June 2019].

20. Official Website of the City of Niš, 2019. [online] Available at: <http://www.ni.rs> [Accessed 16 June 2019].

21. Official Website of the Constantine the Great Airport, 2019. [online] Available at: <https://nis-airport.com/istorijat/> [Accessed 16 June 2019]. 
TOURIST RESOURCES OF THE CITY OF NIŠ IN THE FUNCTION OF ITS DEVELOPMENT AS AN URBAN TOURIST DESTINATION

22. Official Website of the Tourist Organization of City of Niš, 2019. [online] Available at <http://www.visitnis.com/> [Accessed 9 January 2019].

23. Official Gazette of the City of Niš, 2011. Spatial Plan of the Administrative Area of the City of Niš 2021, Niš.

24. Page, S., 1995. Urban Tourism. Routledge.

25. Peroš, L., 2013, Affirmation of cultural identity tourism destination through city break travelling-Zadar city example. The Third International Scientific Congress-Biennale:Icon Best 2013, 5-7 August 2013, Skopje: Macedonia.

26. Podovac, M., 2016. Gradski turizam kao razvojna šansa turizma grada Kragujevca. BizInfo (Blace) Journal of Economics, Management and Informatics, 7 (2), str. 1-13.

27. Popescu, I. R. and Profiroiu, G. A., 2012. Comparative Study Regarding EU Urban Areas Tourism Promotion Using Official Websites - Examples of Good Practices for Romania's Capital City. Transylvanian Review of Administrative Sciences, No. 35, pp. 219237.

28. Popesku, J., 2016. Menadžment turističke destinacije. Beograd: Univerzitet Singidunum.

29. Prideaux. B., 2009. Resort Destinations - Evolution, Management and Development. Elsevier Ltd.

30. Republic of Serbia, Census of Population 2011. [online] Available at: <http://popis2011.stat.rs/> [Accessed 13 December 2017].

31. Statistical Office of the Republic of Serbia, Municipalities and regions in the Republic of Serbia (2011-2018.). [online] Available at: <http://www.stat.gov.rs/oblasti/ugostiteljstvo-i-turizam/> [Accessed 18 April 2019].

32. Statistical Office of the Republic of Serbia, Employees in the Republic of Serbia, 2018. [online] Available at: <http://publikacije.stat.gov.rs/G2019/Pdf/G20191017.pdf> [Accessed 18 April 2019].

33. Secretariat for Environmental Protection of the City of Niš, 2017. City of Niš Environmental Program with Action Plan 2017-2027. Niš.

34. Šušić, V. i Mojić, J., 2014. Kongresni turizam kao tržišna niša poslovnog turizma. Ekonomske teme, 52 (4), str. 523-539.

35. Zečević, B., 2007. Marketing turističkih destinacija - uloga informacione tehnologije. Jugo knjiga komerc.

Received: 8 December, 2019

Accepted: 17 December, 2019

Rad je primljen: 08.12.2019.

Prihvaćen za objavljivanje: 17.12.2019. 
